\title{
Association between emotional intelligence and academic achievement among undergraduates: A cross-sectional quantitative study in KUST, Pakistan
}

\section{Questionnaire for Undergraduates}

\section{$\underline{\text { Section - A: Demographic Information }}$}

Name:

Gender:

Age:

Name of Department:

Academic Programme:

Current CGPA (mandatory):

Day scholar/Boarder:

Father's Education:

Parental Income per month:
Current Semester:

Locality (Urban/Rural):

Religion:

Mother's Education:

\section{Section - B: Emotional Intelligence}

Please read each statement carefully and decide how you feel about your emotional intelligence described by the statements.

Scale:

$\begin{array}{lll}1= & \text { Strongly Disagree } & (\text { SDA }) \\ 2= & \text { Disagree } & \text { (DA) } \\ 3= & \text { Uncertain } & (\mathrm{U}) \\ 4= & \text { Agree } & (\mathrm{A}) \\ 5= & \text { Strongly Agree } & (\mathrm{SA})\end{array}$


Please indicate on a scale of 1 to 5; for example, encircle 5 If you Strongly Agree (SA), or encircle 1 if you Strongly Disagree (SD) and so on.

\begin{tabular}{|c|c|c|c|c|c|c|}
\hline S.\# & Statements & SDA & DA & $\mathbf{U}$ & $\mathbf{A}$ & $\mathbf{S A}$ \\
\hline 1. & $\begin{array}{l}\text { I can encourage others to work even when things are not } \\
\text { favorable. }\end{array}$ & & & & & \\
\hline 2. & People tell me that I am an inspiration for them. & & & & & \\
\hline 3. & I am able to encourage people to take initiative. & & & & & \\
\hline 4. & $\begin{array}{l}\text { I am able to make intelligent decisions using a healthy } \\
\text { balance of emotions and reason. }\end{array}$ & & & & & \\
\hline 5. & I do not depend on others encouragement to do my work well. & & & & & \\
\hline 6. & $\begin{array}{l}\text { I can continue to do what I believe in, even under severe } \\
\text { criticism. }\end{array}$ & & & & & \\
\hline 7. & I am able to assess the situation and then behave. & & & & & \\
\hline 8. & I can concentrate on the task at hand in spite of disturbances. & & & & & \\
\hline 9. & I can attention to the worries and concerns of others. & & & & & \\
\hline 10. & I can listen to someone without the urge to say something. & & & & & \\
\hline 11. & I can perceive as friendly and outgoing. & & & & & \\
\hline 12. & I have my priorities clear. & & & & & \\
\hline 13. & I can handle conflicts around me. & & & & & \\
\hline 14. & I do not mix unnecessary emotions with issues at hand. & & & & & \\
\hline 15. & I try to see the other person's point of view. & & & & & \\
\hline 16. & I can stand up for my beliefs & & & & & \\
\hline 17. & I can see the brighter side of my situation. & & & & & \\
\hline 18. & I believe in myself. & & & & & \\
\hline 19. & I am able to say composed in both good and bad situations. & & & & & \\
\hline 20. & I am able to say focused even under pressure. & & & & & \\
\hline 21. & I am able to maintain the standards of honesty and integrity. & & & & & \\
\hline 22. & I am able to confront unethical actions of others. & & & & & \\
\hline 23. & I am able to meet commitments and keep promises. & & & & & \\
\hline 24. & I am organized and careful in my work. & & & & & \\
\hline 25. & I am able to handle multiple demands. & & & & & \\
\hline 26. & $\begin{array}{l}\text { I am comfortable and open to novel ideas and new } \\
\text { information. }\end{array}$ & & & & & \\
\hline 27. & I purser gales beyond what is require and expected of me. & & & & & \\
\hline 28. & $\begin{array}{l}\text { I am persistent in pursing goals despite obstacles and } \\
\text { setbacks. }\end{array}$ & & & & & \\
\hline 29. & $\begin{array}{l}\text { I have built rapport and made and maintained personal } \\
\text { friendships with work association. }\end{array}$ & & & & & \\
\hline 30. & I am able to identity and separate my emotions. & & & & & \\
\hline 31. & I think that feelings should be managed. & & & & & \\
\hline 32. & I am aware of my weakness. & & & & & \\
\hline 33. & $\begin{array}{l}\text { I feel that I must develop myself even when my job dose not } \\
\text { demand. }\end{array}$ & & & & & \\
\hline 34. & I believe that happiness is a positive attitude. & & & & & \\
\hline
\end{tabular}

Thank you very much......... 